\title{
GRAVITATIONAL MODEL OF POPULATION DYNAMICS
}

\author{
M.Y. Khavinson, M.P. Kulakov \\ Institute for Complex Analysis of Regional Problems FEB RAS, Birobidzhan, \\ Russian Federation \\ E-mail: havinson@list.ru, k_matvey@mail.ru
}

\begin{abstract}
We consider the author's mathematical model of population dynamics of territories, taking into account the migration between the territories. The model is a system of ordinary differential equations with constant coefficients. The main idea of the presented modelling is to take into account the migration interactions of territories in the form of nonlinear terms (they are the pair products of phase variables of the territories population). On the one hand, the approach allows to consider the model as a variant of expanding the gravitational approach in migration studies. On the other hand, this approach allows to apply the approaches of mathematical biology, which are successfully used in econophysics and sociodynamics. In order to verify the model, we use statistical data on population and migration between federal districts of the Russian Federation. The results of the modelling show the significance of the "repulsion" of migrants arriving in the Central and NorthWestern federal districts, mainly in the nearby regions (Southern, North Caucasian and Volga federal districts). Model evaluations of the migration balance are obtained. The evaluations exceed statistical ones by dozens of times and, to all appearances, describe the "latent" migration of the population, covering both long-term and short-term movements. An analysis of the change in the stationary values of the population for a linear change in the parameters is carried out. It is shown that there are such values of the parameters of migration attractiveness of the Russian Federation federal districts, under which the population increases both in the whole in the Russian Federation and in individual districts. It is established that such changes can occur due to significant differences in the opportunities, which are "provided" by different federal districts for migrants (e.g., living and working conditions, upbringing and education of children, etc.), and intra-Russian migration.
\end{abstract}

Keywords: gravitational approach; migration; population; federal districts of the Russian Federation; ordinary differential equations.

\section{Introduction}

Migration of the population is an important indicator of territories development, and "voting with their feet" expresses their cultural and socio-economic attraction or repulsion [1-4]. One of the main and already classical approaches to the quantitative evaluation of migration is the gravitational approach. It is based on the physics idea about the attraction of cosmic bodies: the larger the body, the greater the force of attraction. Any object having mass also has gravity, and interacting objects are attracted to each other with a certain force. Taking into account that many theories of the society development are based on the concepts of natural science [5,6], the migration researchers also find the idea of gravitation sufficiently suitable for describing the mechanical movement of the population. In the gravitational approach, the population is a prototype of the cosmic body mass. Exactly the population determines the development of the territory, and the larger the population, the more there are social structures, physical and virtual communications. The settlements are divided into categories (towns, urban-type settlements, cities, etc.) 
precisely by the size of the population. The distance is a factor that reduces effect of the migration gravitational forces. Indicators of settlements interaction, according to which the intensity of the corresponding migration flows is calculated, are determined on the basis of the gravitational approach [7].

The basic gravity model of migration has the following form:

$$
M_{i j}=k \frac{p_{i} p_{j}}{d_{i j}^{2}}
$$

where $M_{i j}$ is a force of migratory attraction between settlements (regions) $i$ and $j, k$ is a compliance coefficient, $p$ is a population of settlements (regions) $i$ and $j, d_{i j}^{2}$ is a distance between settlements (regions) [7]. Note that such models are also used to describe the interaction of regions and countries in the aspect of trade and investment $[8,9]$.

One of the disadvantages of this approach is the static nature of indicators. Migration depends on the number of settlements, and this number annually changes as a result of changes in the birth rate, mortality and features of the population's mechanical movement. In order to get a forecast it is necessary to develop a dynamic model that describes both the population change as a whole and gravitational interactions. The econophysical concept of information interactions, described by D.S. Chernavsky [10], is very suitable. Mathematically, it is expressed in the form of a system of equations:

$$
\frac{d u_{i}}{d t}=\frac{1}{\tau_{i}} u_{i}-\sum_{j \neq 0}^{n} b_{i j} u_{j} u_{i}-a_{i} u_{i}^{2}+D_{i} \Delta u_{i},
$$

where $u_{i}$ is a number of carriers of information; $u_{j}$ is a number of carriers of information $j ; \tau_{i}, b_{i j}, a_{i}$ are model parameters; $D_{i} \Delta u_{i}$ is a spatial distribution of information carriers. In other words, the first term on the right side describes a reproduction of the information $i$, the second - an interaction of the different information carriers, the third - some external restrictions, the fourth - a migration of information carriers in space. This model is used in the natural sciences (the authors of the model, A.J. Lotka and V. Volterra, proposed the model independently in the 1920s) to describe the dynamics of the size of interacting populations (for example, the "predator-prey" type), as well as the interaction of chemicals [11]. Using this type of equations system, the oscillations and complex regimes of population dynamics are described in the mathematical biology [12-14]. The following important principle of modelling the interaction of living systems is used in these models: pair interactions in the equations are described by products $u_{i} u_{j}$, where $u_{i}$ is the size of $i$-th population, $u_{j}$ is the size of $j$-th population. It was assumed that changes in the size of populations are caused by direct "collisions" of individuals (the coefficient at $u_{i} u_{j}$ indicated which proportion of the individuals meetings entails a change in the size of populations), in addition to the processes of mortality and reproduction. For example, in some cases the result of the interaction of a predator and a prey is such that the predator eats the prey, and, as a consequence, the predator biomass increases (as well as conditions for the predator reproduction) and the prey number decreases. Therefore, it is clear from the equations that paired interactions in biology are a "prototype" of gravitational interactions in describing migration. The studies of sociodynamics by W. Widlich were based on this idea. He developed conceptual probabilistic models of migration between three regions in which complex, including chaotic, dynamics were discovered [15]. However, these models were not applied to specific objects. 
In this study, in order to construct a dynamic gravitational model, as has already noted, an econophysical approach, generalized by D.S. Chernavsky and including both the most possible simplicity and sufficiently rich modelling capabilities, is used. In addition, the developed model is verified on specific socio-economic objects which population dynamics is described by the corresponding statistical data.

\section{The Concept of a Dynamic Gravitational Model of Population Migration}

The general form of the dynamics model of the population size for $N$ coupled territories is the following:

$$
\dot{x}_{i}=\frac{d x_{i}}{d t}=f\left(x_{i}\right)-\sum_{j=1, j \neq i}^{N} m_{j i} x_{i}+\sum_{j=1, j \neq i}^{N} m_{i j} x_{j}(i=1,2, \ldots, N),
$$

where the first term is a function of local reproduction, which determines the population growth in the $i$-th territory in the case when there is no external migration, the second and third terms are contributions to the growth due to multidirectional migration flows (Fig. 1). In general case, parts of migrants $m_{i j}$ are functions that can depend on many factors.

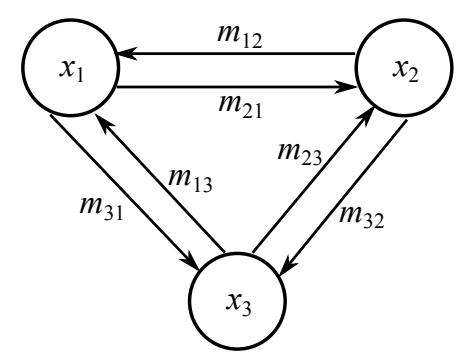

Fig. 1. The general scheme of migration movements between three territories, where $x_{i}$ is a size of the population of $i$-th territory, arrows shows directions of the migration, $m_{i j}$ is a part of migrants moving from the $j$-th territory to the $i$-th territory

Now we consider the case when the migration part is directly proportional to the population of the territory to which the migration is directed, and inversely proportional to the distance between the territories. In this case:

$$
m_{i j}=\frac{\alpha_{i j} x_{j}}{r_{i j}^{2}}
$$

where $r_{i j}=r_{j i}$ is a distance between the $i$-th and $j$-th territories, $\alpha_{i j}$ is a coefficient expressing the attractiveness of the $j$-th territory for the population of the $i$-th territory. Then system (1) has the form:

$$
\dot{x}_{i}=f\left(x_{i}\right)-\sum_{j=1, j \neq i}^{N} \frac{\alpha_{j i} x_{i} x_{j}}{r_{j i}^{2}}+\sum_{j=1, j \neq i}^{N} \frac{\alpha_{i j} x_{i} x_{j}}{r_{i j}^{2}}(i=1,2, \ldots, N) .
$$


We factor out $x_{i} x_{j}$ in $(2)$ :

$$
\dot{x}_{i}=f\left(x_{i}\right)+\sum_{j=1, j \neq i}^{N} x_{i} x_{j}\left(\frac{\alpha_{i j}}{r_{i j}^{2}}-\frac{\alpha_{j i}}{r_{j i}^{2}}\right)(i=1,2, \ldots, N) .
$$

Note that the distance between the $i$-th and $j$-th territory is equal to the distance between the $j$-th and $i$-th territory, i.e. $r_{i j}=r_{j i}$. Therefore, we set:

$$
\frac{\alpha_{i j}-\alpha_{j i}}{r_{i j}^{2}}=s_{i, j}
$$

As a result, the system (2) takes the form:

$$
\dot{x}_{i}=f\left(x_{i}\right)+\sum_{j=1, j \neq i}^{N} s_{i j} x_{i} x_{j}(i=1,2, \ldots, N) .
$$

In the case when $N=3$, corresponding to the migration of the population between three territories, which is schematically shown in Fig. 1, the model (3) takes the form:

$$
\left\{\begin{array}{l}
\dot{x}_{1}=f\left(x_{1}\right)+s_{12} x_{1} x_{2}+s_{13} x_{1} x_{3} \\
\dot{x}_{2}=f\left(x_{2}\right)-s_{12} x_{1} x_{2}+s_{23} x_{2} x_{3} \\
\dot{x}_{3}=f\left(x_{3}\right)-s_{13} x_{1} x_{3}-s_{23} x_{1} x_{3}
\end{array}\right.
$$

In this case, the terms $s_{12} x_{1} x_{2}, s_{13} x_{1} x_{3}$ and $s_{23} x_{2} x_{3}$ are easily interpreted as the migration balance (i.e., the difference between the arrived and the outgoing persons) between the first and the second, the first and the third, the second and the third territories, respectively.

Suppose that population growth is limited, i.e. a size of the population tends to a stationary level, which somehow modifies the migration of the population. Then, in order to describe the local dynamics, we can use the well-proven model of limited growth, that is a modified Malthusian growth model with constant migration: $\dot{x}=f(x)=b-k x$. For positive parameters, the model has two types of solution. They are a monotonous growth and a decline to a stationary population size, which is equal to $b / k$ [11]. Then (4) has the form:

$$
\left\{\begin{array}{l}
\dot{x}_{1}=b_{1}-k_{1} x_{1}+s_{12} x_{1} x_{2}+s_{13} x_{1} x_{3} \\
\dot{x}_{2}=b_{2}-k_{2} x_{2}-s_{12} x_{1} x_{2}+s_{23} x_{2} x_{3} \\
\dot{x}_{3}=b_{3}-k_{3} x_{3}-s_{13} x_{1} x_{3}-s_{23} x_{2} x_{3} .
\end{array}\right.
$$

The sense of the term $s_{i j} x_{i} y_{j}$ is to indicate the possibility of calculating the migration balance between the $i$-th and $j$-th territories, as the sums of all facts of transfer between these territories for a certain time period (including short-term transfers, and not just relocations), for example, for one year. To this end, we set the initial conditions at $t_{0}=0$, i.e., we choose the values $x_{1}(0), x_{2}(0), x_{3}(0)$, as well as the values of all parameters. Then we can numerically solve the system $(5)$ for some small integration step $1 / h \in(0,1)$ $(h \in \mathbb{N})$. As a result, we get a time series $x_{i}(t)$, where $t=t_{0}+n / h$ and $n=0,1,2, \ldots, N$. In this case, the total balance for one year, i.e. for the time between $\tau$ and $\tau+1$, is equal to the integral of the form:

$$
S_{i j}(\tau+1)=\int_{\tau}^{\tau+1} s_{i j} x_{i}(t) x_{j}(t) d t \cong \frac{1}{h} \sum_{n=0}^{N} s_{i j} x_{i}(\tau+n / h) x_{j}(\tau+n / h),
$$


where the values $x_{i}(\tau+n / h)$ are set to be equal to already numerically found solutions of the system (5). In this case, the integral is estimated by the rectangle formula. It is justified, since the behavior of the solutions (5) for the time between $\tau$ and $\tau+1$, as a rule, is changed quite slowly.

\section{Parametric Identification of the Model}

The developed model is applied to the description of migration dynamics between federal districts of Russia for 1996-2014. Statistics are taken from open sources of the Federal State Statistics Service [16]. The Crimean federal district is not examined, because currently the relevant statistics for this district are limited to 2014. In order to test the model in a basic three-dimensional version containing the whole variety of dynamic regimes, the federal districts are grouped into three groups. The criterions of the grouping are territorial proximity, similar demographic trends and the level of socio-economic development. The first group includes the Central and North-Western federal districts (we denote this group by 1), the second group includes the Southern, North Caucasian and Volga federal districts (we denote this group by 2), the third group includes the Ural, Siberian and Far Eastern federal districts (we denote this group by 3). Undoubtedly, there is no complete homogeneity in terms of demographic trends and socio-economic development in these groups, as well as there is no such homogeneity in the regions of the federal districts. Nevertheless, the demographic trends associated with spatial heterogeneity (including socio-economic) are quite clear in the considered territories. Fig. $2(a)$ shows that after a long-term decrease of Russia's population since 2008, the demographic situation began to improve. And it is noticeable that the farther from the central part of Russia the territory is located, the more slowly the population increases (Fig. $2(b),(c),(d))$. In recent five years, the intensity of migration flows between the
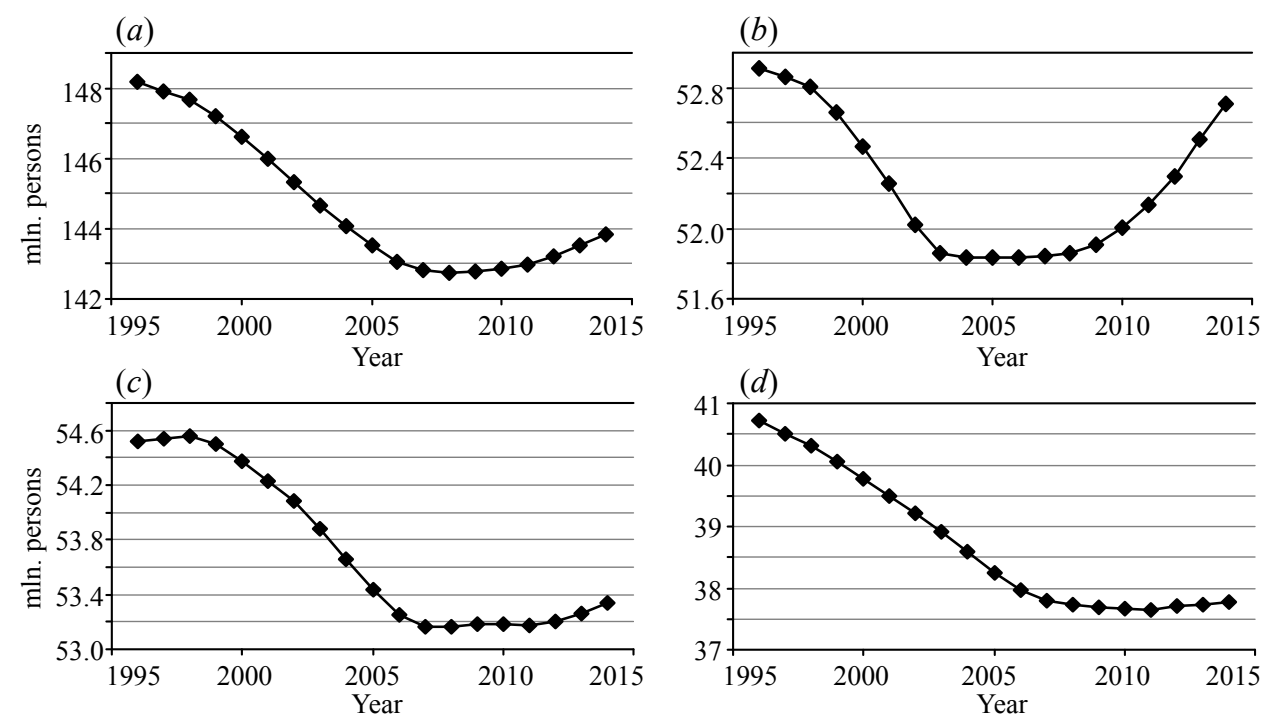

Fig. 2. Population in the Russian Federation and groups of federal districts: $(a)$ the Russian Federation; (b) Central and North-Western federal districts; $(c)$ Southern, NorthCaucasian and Volga federal districts; $(d)$ The Ural, Siberian and Far Eastern federal districts 
considered territories has increased (Fig. 3). At the same time, it is impossible uniquely single out the reasons for such growth. The first reason can be the natural population growth in the departure territories or the increased attractiveness of the arrival territories (as well as the reduced attractiveness of the departure territory). The second reason can be the changes in the registration procedure for migrants. Figure $3 a$ shows the official number of people who changed their place of residence from the $j$-th group of federal districts to the $i$-th one (by analogy with the coefficient $m_{i j}$ in the system (1)), which is denoted by $\mu_{i j}$. Then the dynamics of the migration balance between the $i$-th and $j$-th territories is calculated as the difference $\mu_{i j}-\mu_{j i}$, the sign of which indicates the direction of migration flows (Fig. $3(b)$ ). According to the official statistics, the migration balance is negative for all territories. For example, the number of migrants in territory 1 from territory 2 is more than the number of migrants which arrive in 2 from 1 . According to these data the most intensive migratory flows are directed from the eastern territories of Russia to the western ones. However, migration statistics is based on arrival and departure records, which are compiled when registering or withdrawing from the population's registration records at the place of residence [17]. Therefore, the official migration data reflects only the facts of movement registration and, in this sense, does not describe all types of migratory interactions, including short-term business trips, business and tourist trips, as well as facts of residence without registration. At the same time, all such population movements determine the degree of attractiveness and unattractiveness of the territories, traffic flows, social ties, and demographic dynamics. The proposed dynamic model allows to estimate the "real" gravitational movement of people and the effect of migration on population change $S_{i j}$ by the formula (6), which has a different meaning than the difference $\mu_{i j}-\mu_{j i}$.

(a)

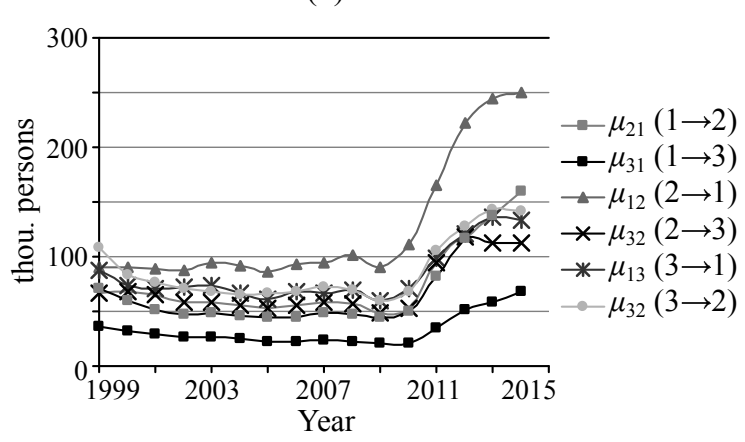

(b)

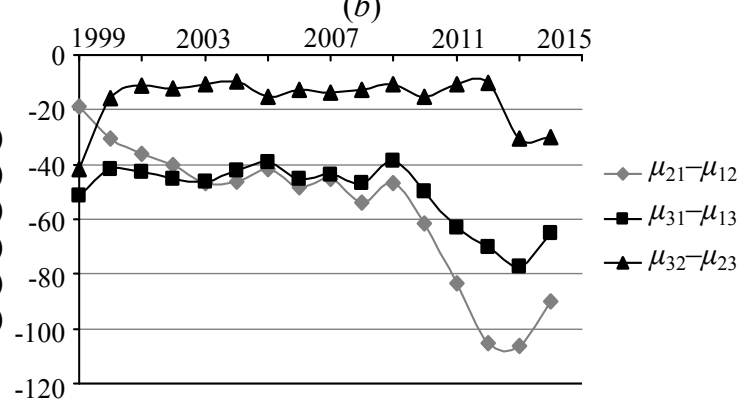

Fig. 3. (a) The official number of migrants between groups of federal districts 1,2 and 3 (between the territories of departure $\rightarrow$ arrival), $(b)$ the migration balance between these territories

In order to use such estimates, it is necessary to carry out a parametric identification of the model, i.e. to estimate the parameters of the model by the available statistical data. The coefficients of the model were estimated in the MathCad by the Levenberg Marquardt method by minimizing the sum of squares of differences between the actual data and the corresponding coordinates of the points of integral curves, i.e. the solutions of the optimization problem having the form: 


$$
\begin{aligned}
J(u)=\sigma_{1} \sum_{j=1}^{N} & \left(x_{1}^{*}\left(t_{j}\right)-x_{1}\left(t_{j}, u\right)\right)^{2}+\sigma_{2} \sum_{j=1}^{N}\left(x_{2}^{*}\left(t_{j}\right)-x_{2}\left(t_{j}, u\right)\right)^{2}+ \\
& +\sigma_{3} \sum_{j=1}^{N}\left(x_{3}^{*}\left(t_{j}\right)-x_{3}\left(t_{j}, u\right)\right)^{2} \rightarrow \min _{u \in D}
\end{aligned}
$$

where $u=\left(b_{1}, b_{2}, b_{3}, K_{1}, K_{2}, K_{3}, \alpha_{12}, \alpha_{13}, \alpha_{21}, \alpha_{23}, \alpha_{31}, \alpha_{32}\right)^{T}$ is a vector of the required coefficients of the system $(5), x_{1}\left(t_{j}, u\right), x_{2}\left(t_{j}, u\right)$ и $x_{3}\left(t_{j}, u\right)$ is a solution of the system (5) at time $t_{j}$, which is obtained by the Adams - Bashfort method, $x_{1}^{*}\left(t_{j}\right), x_{2}^{*}\left(t_{j}\right)$ and $x_{3}^{*}\left(t_{j}\right)$ are the actual populations of the considered groups of regions. The weight coefficients $\sigma_{i}$ $\left(\sigma_{1}+\sigma_{2}+\sigma_{3}=1\right)$ show the relative importance of the particular criteria of the optimization problem $J(u) \rightarrow$ min. In addition, when choosing the best approximation, the quality of approximation to the total indicator, i.e. the total population in the region $\left(x_{1}+x_{2}+x_{3}\right)$, is taken into account. As a result, it is possible to achieve a good match between model and real dynamics. Also, the corresponding statistical tests (the Fisher criterion on the normal nature of the residue distribution, the Darbon - Watson test on the absence of autocorrelation of the residues) were calculated and show the statistical significance of the estimates.

As a result, the following estimates of the parameters of the model (5) were obtained:

$$
\left\{\begin{array}{c}
\dot{x}_{1}=-0,663+0,383 x_{1}-0,026 x_{1} x_{2}-0,03 x_{1} x_{3}, \\
\dot{x}_{2}=1,475-0,476 x_{2}+0,026 x_{1} x_{2}+0,016 x_{2} x_{3}, \\
\dot{x}_{3}=0,398-0,175 x_{3}+0,03 x_{1} x_{3}-0,016 x_{2} x_{3} .
\end{array}\right.
$$

The meaning of the estimates of the model parameters is as follows. Statistical data on the population, in our opinion, are generally reliable. Nevertheless, if the increase in this number is decomposed into additive components of natural (fertility and mortality) and mechanical population growth (migration), then the migration estimates are the least accurate indicators. Population data are used within the model approach described, and all other parameters are estimated based on the concept of the model and numerical methods. At the same time, the coefficients are averaged over the period 1996-2014. The obtained estimates of the model parameters in some cases diverge from the statistical data, for example, the calculated orientation of the migratory flows turned out to be unexpected. As noted, according to statistical data (the migration balance was calculated), Russians move from east to west. However, according to the model's estimates, it turns out that the second group of federal districts, including the Southern, North Caucasian and Volga federal districts, is favorable for migrants, and the third group of districts, i.e., the Ural, Siberian and Far Eastern federal districts, is a kind of intermediate point in their migration to the second group of districts (Fig. 4).

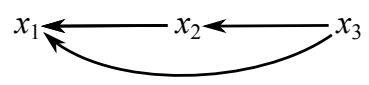

(a)

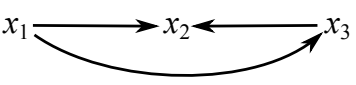

(b)

Fig. 4. The direction of domestic migration flows in Russia: (a) statistical data; $(b)$ model calculations

It is probably due to many facts of the migrants return from the Central and NorthWestern federal districts. A similar effect can be observed at the level of international 
migration (re-emigration). According to modelling results, on average during the period under review, the central federal districts became regions of repulsion. The districts accumulate the best qualified personnel and push out migrants who could not adapt to the new conditions of life. It turns out that the second group of federal districts under review is the migratory recipient. At the same time, the central regions "return" approximately the same parts of migrants to the regions of the second and third groups $\left(s_{12}=-0,026\right.$, $\left.s_{13}=-0,03\right)$.

We can explain the difference between qualitative model results and statistical data as follows. According to the statistics, the number of migrants is bigger in the regions where their accounting is better organized. A high level of migrants registration is quite obvious, because the central regions are key in Russia for socio-economic development, the focus of culture and tourism, and significant transport international and national nodes.

According to our estimates, between 1996 and 2014, the average migration balance between 1 and 2 regions is 7,8 million people, between 2 and 3 regions is 5,8 million people, between 1 and 3 regions is 3,4 million people. The large discrepancy between the calculated and statistical data can indicate, firstly, a significant undercount of migrants, and secondly, the significant role of other factors affecting population growth in the regions (for example, marriages between people who have a permanent place of residence in different regions).

According to the aggregated model estimates of international migration (balance estimate), population movement in the first group is directed from Russia $\left(b_{1}<0\right)$, and in other groups the movement is directed to Russia $\left(b_{2}>0, b_{3}>0\right)$. We explain this by proximity of the central region to Europe and the financial capabilities of its population to travel abroad. Conversely, for other regions, there are no such opportunities for the population because of growing migration from the CIS countries. Herewith, the most favourable conditions for the natural reproduction of the population are provided by the central regions $\left(k_{1}=-0,381, k_{2}=0,476, k_{3}=0,175\right)$.

\section{Forecast of the Russian Federation Population on the Basis of the Dynamic Gravitational Model}

Based on the model estimates, the forecast of the population in the regions and the Russian Federation as a whole is obtained. Fig. 5 shows that we should expect an increase in population until 2035, and then we expect a small drop that is a part of the damped oscillations (steady focus). Undoubtedly, such long-term forecast seems to be improbable, since the estimates are obtained by rather short time series, and the model does not take into account the non-permanent nature of the demographic parameters. However, in the medium term, the forecast can be taken into consideration.

In order to continue the studies based on the point estimates of parameters, we can perform a "local" analysis of their stability in a neighbourhood. Fix values of the parameters and vary alternately all of them, in order to investigate the stability of each singular point. This will not only identify the stability region of the obtained estimate, but also evaluate the transformation of phase trajectories, in particular, describe the regions of attraction of stable regimes. In order to calculate the stationary points, we use the following author's numerical-symbol method. From the system of three nonlinear algebraic equations, we obtain a fifth degree polynomial and numerically search the polynomial roots by the companion matrix method. As a result, for a particular set of parameters, we can 

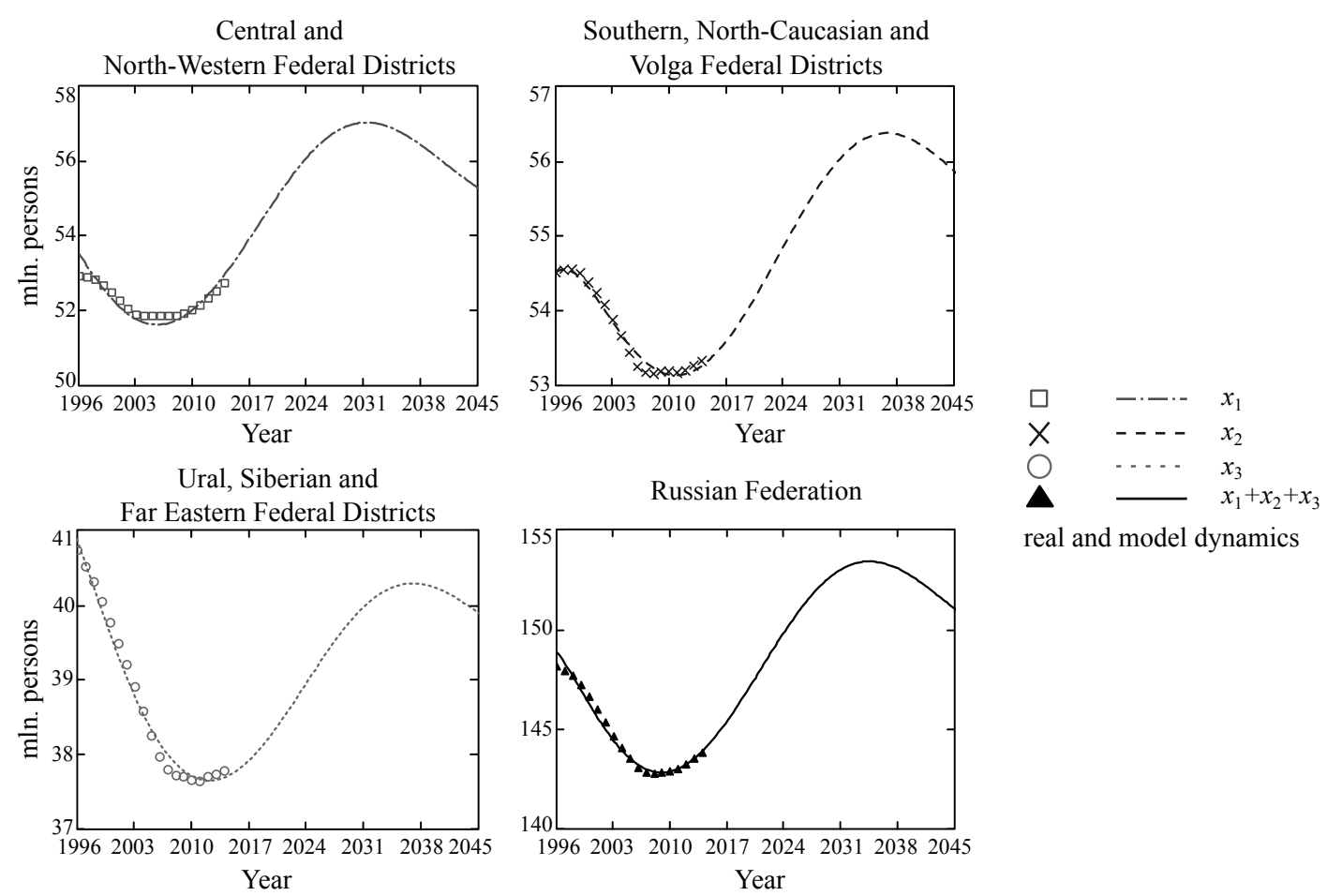

real and model dynamics

Fig. 5. Forecast of the Russian Federation population

find all its specific points and obtain their dependence on the parameters (Fig. 6 and Fig. 7). Next, it is easy to calculate a spectrum of the eigenvalues of the linearized system in the neighborhood of each singular point and to say about the nature of the stability. In the simplest case, it is enough to estimate, whether a stationary point is stable or unstable. That is, whether the real part of each eigenvalue is not more than zero. To this end, we can use, for example, the Routh - Hurwitz criterion. However, this will not allow to separate the singular points into fully stable (saddle and focus), "semi-stable" (saddle, saddle-focus) and fully unstable. As a consequence, this will not allow to say about the global dynamics of all possible phase trajectories. Therefore, we will consider the values of the eigenvalues of all singular points, comparing them with each other and defining stable and unstable manifolds.

Fig. 6 shows the dependence graphs for one of the coordinates of the singular point of the system (5) with the variation of each of its parameters. In addition, the diagram schematically shows the stability type and mark a range of parameters corresponding to the existence of a fully stable singular point (stable focus).

On the basis of the stationary state diagram, the dependences of stable stationary states (stationary populations of each group of regions) are constructed with a change in the system parameters (Fig. 7).

It turned out that the point estimate of the parameters is almost everywhere near the stability boundary and allows the growth of migration parameters to their maximum values. This variation, in particular, allows a change in the sign of the coefficient $s_{i j}$, which indicates the possibility of a change in the direction of migration without a drastic change in the type of dynamics. Also, it is easy to see that the change in parameters causes a change in the steady stable state. It is manifested in the fact that the population of some groups of regions increases, while the population of others groups falls. Moreover, this 


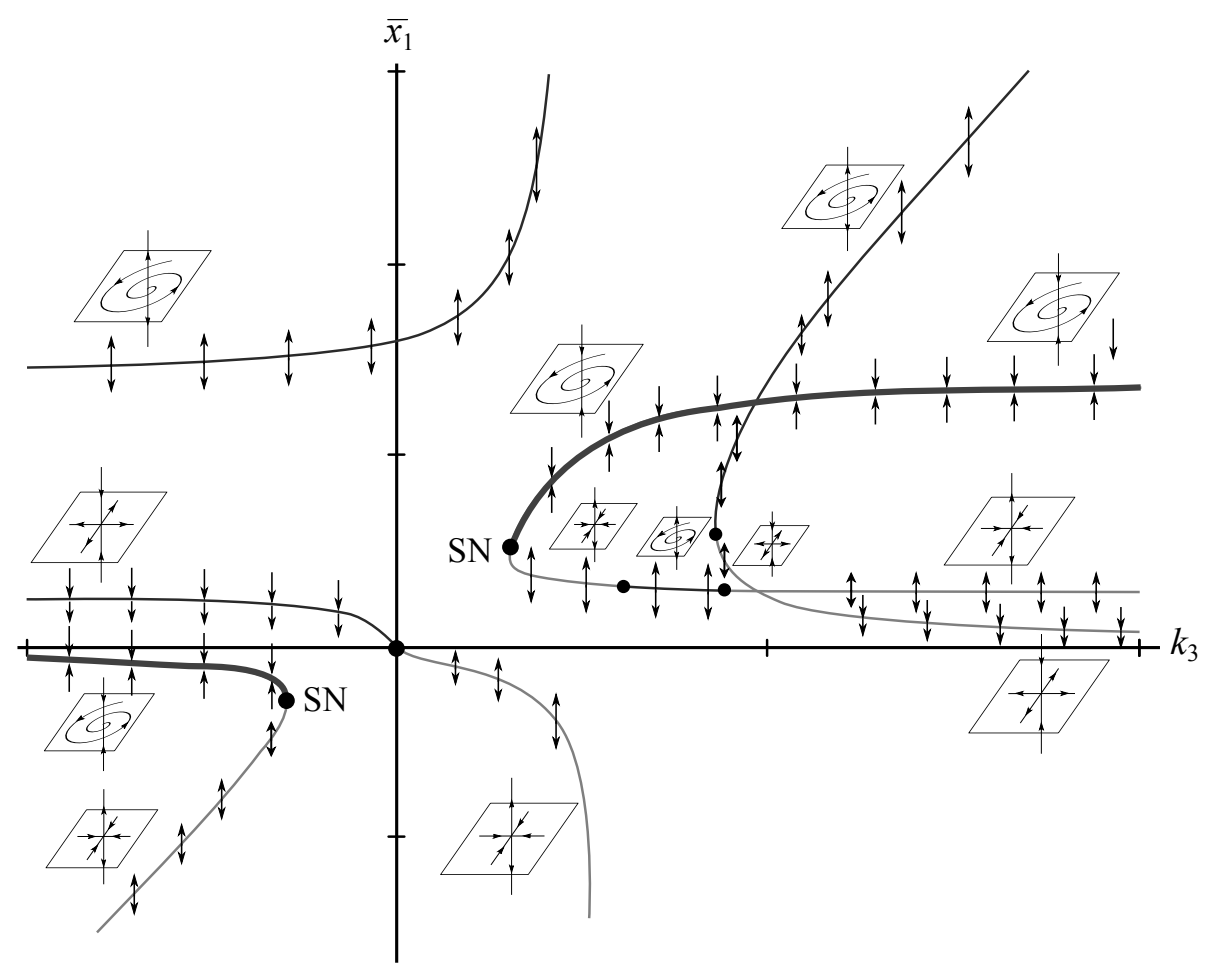

Fig. 6. Typical form of the stationary states diagram (bifurcation diagram) with variation of the parameter $k_{3}$. The stability type of each point is shown in the figure (the fully stable state is shown by a thick line), the bold points show the simplest bifurcations of codimension 1 ( $\mathrm{SN}$ is saddle-node and bifurcations change in the type of stability)

change is not always monotonous. For example, the attractive growth of the 1st region for the 3rd one $\left(s_{13}\right)$ leads to a strong growth of the stationary population in the 1st and 2nd regions and a rather strange nonmonotonic behavior of the population in the 3rd. In the beginning, the outflow of population from the 3rd region will increase the population in the 1st, and the population of the 1st (while the values of other migration parameters are preserve) will actively begin increase the population of the 2 nd region (due to crowding out the population), which will increase the population of the $3 \mathrm{rd}$. As a result, the population of all regions will grow. This is due to the fact that these territories have different own growth rates, and according to the ideology of the model, the population growth is directly proportional to the number and is different for the territories. That is, the people coming from the 3rd region will become indistinguishable from the local people and will participate in reproduction with the parameters of the 1st and 2nd territories. Next, the outflow of the population from the 3rd region is no longer compensated by the inflow from the 2 nd, because the outflow in the 1st considerably exceeds the inflow from the 2nd, and the growth of the stationary population stops, and then the growth falls to low values. Moreover, it remains so even with a change in the direction of migration. A similar dependence is observed for the other two migration parameters.

\section{Conclusion}

As a result of the modelling, the principal results were obtained on the basis of the gravitational approach. First, the directions of migration movements (migration balance), 
(a)

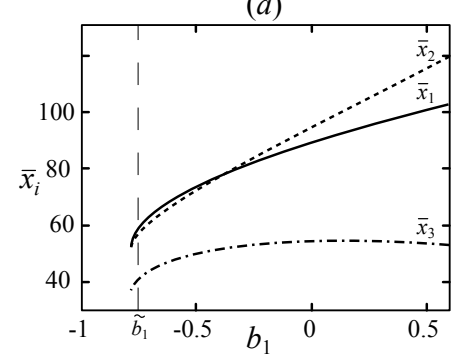

(d)

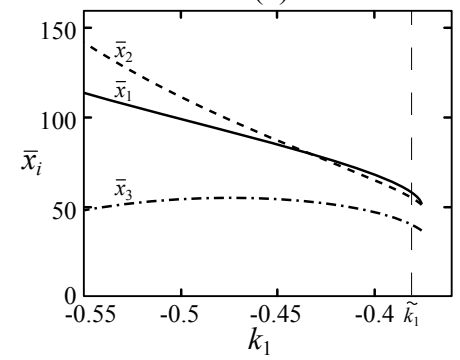

(g)

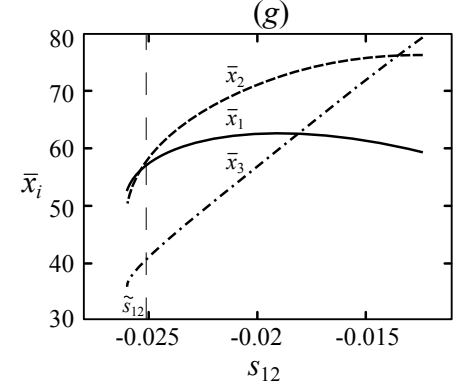

(b)

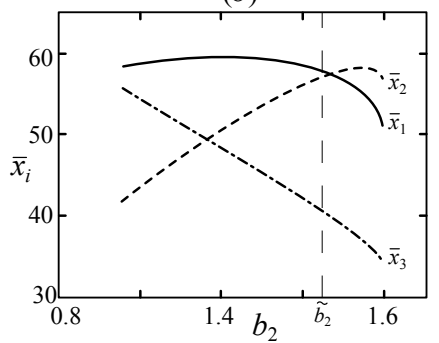

(e)

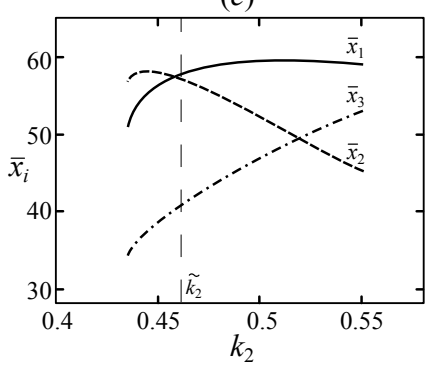

(h)

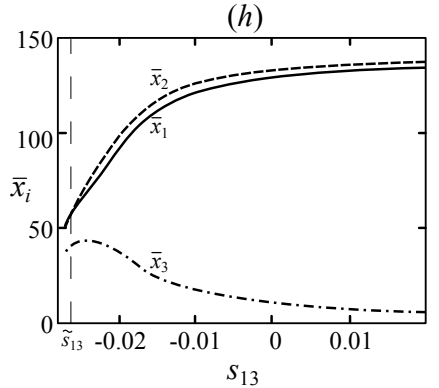

(c)

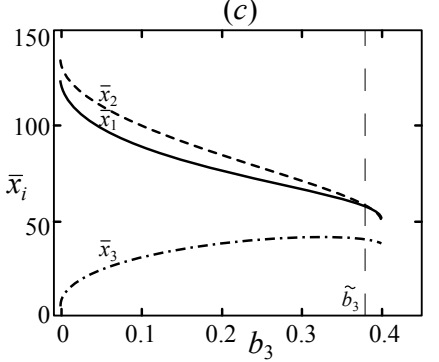

$(f)$

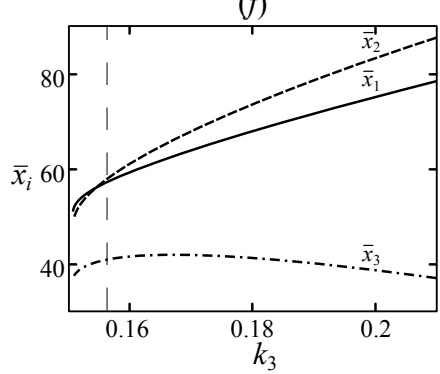

(i)

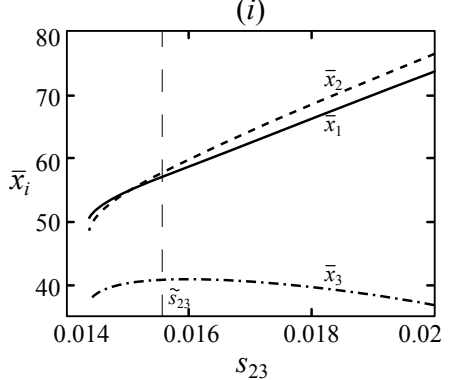

Fig. 7. Dependence of stable stationary states (stationary population of each group of regions) with a change in the parameters of the system (5). Vertical dotted line is a point estimation of the parameters

affecting the demographic dynamics in the considered regions, do not correspond to the statistical data of migrants' records. According to statistics, the population in Russia is stable and gradually moves from east to west. The obtained calculations do not contradict such tendencies and show the significance of "repulsion" of the Central and North-Western federal districts mainly in the nearby territories of the country (Southern, North-Caucasian and Volga federal districts). Secondly, estimates of the migration balance affecting the recorded population exceed statistical ones by dozens of times. In addition, according to the concept of a dynamic gravitational model, the connections between territories are nonlinear. Therefore, the migration factors and the general picture of population redistribution in Russia can go out of the frame of linear econometric models. In this connection, there is a significant question: What are the real migration processes, and how can population movements be correctly estimate?

As it is known, in our country, a corresponding migration policy is conducted. The policy is especially relevant for sparsely populated territories of the Far East and Siberia [1-3]. Incorrect estimates of the mechanical movement of the population can nullify all attempts both to influence the migration and to improve the demographic situation in certain regions of the Russian Federation. Perhaps in order to evaluate the real situation, it is necessary deeply study migration motives in the context of network information 
interactions by sociologic methods, as well as to apply direct and indirect indicators (for example, transport displacements).

Acknowledgements. The publication was prepared within the grant of the President of the Russian Federation for the state support of young Russian scientists - candidates of sciences No. MK-6255.2016.6.

\section{References}

1. Mishchuk S.N. Peculiarities of International Labour Migration from China to Russia (on the Example of the Far East Federal District). Economy of Region, 2014, vol. 38, no. 2, pp. 194-202. (in Russian)

2. Mischuk S.N. Retrospective Analysis of Migration in Jewish Autonomous Region. Regional Problem, 2015, vol. 18, no. 3, pp. 74-81. (in Russian)

3. Motrich E.L., Naiden S.N. Migration Processes in the Socioeconomic Development of the Far East. Studies on Russian Economic Development, 2015, issue 26, no. 5, pp. 491-498. DOI: $10.1134 / \mathrm{S} 1075700715050093$

4. Khavinson M.Yu., Kulakov M.P., Mishchuk S.N. Prediction of Foreign Labor Migration Dynamics at the Regional Level. Studies on Russian Economic Development, 2013, vol. 24, no. 2 , pp. $170-178$. DOI: $10.1134 /$ S1075700713020068

5. Romanovskij M.Ju., Romanovskij Ju.M. Vvedenie $v$ jekonofiziku: statisticheskie $i$ dinamicheskie modeli [An Introduction to Econophysics: Statistical and Dynamic Models]. Moscow, Izhevsk, Izhevsk Institute of Computer Science, 2012. 340 p.

6. Khavinson M.Yu. Econophysics: from Finance Analysis to the Fate of Mankind. Spatial Economics, 2015, no. 1, pp. 144-166. (in Russian) DOI: 10.14530/se.2015.1.144-166

7. Vasilenko P.V. Gravitation Power and Migratory Mobility of the Regions Population. Immanuel Kant Baltic Federal University's Vestnik. Series: Natural and Medical Sciences, 2013, no. 7, pp. 153-157.

8. Drapkin I.M., Mariev O.S., Chukavina K.V. Gravity Approach towards the Empirical Estimation of Foreign Direct Investment Factors in Russian Economy. Bulletin of Ural Federal University. Series: Economics and Management, 2014, no. 6, pp. 58-66. (in Russian)

9. Kaukin A.S. Features of Empirical Estimates of the Gravity Model of Russian Foreign Trade. Russian Foreign Economic Bulletin, 2013, no. 4, pp. 71-84. (in Russian)

10. Chernavskii D.S. Sinergetika i informacija: Dinamicheskaja teorija informacii [Synergetics and Information: Dynamical Theory of Information]. Moscow, URSS, 2016. 304 p.

11. Riznichenko G.Ju., Rubin A.B. Biofizicheskaja dinamika produkcionnyh processov [Biophysical Dynamics of Production Processes]. Moscow, Izhevsk, Izhevsk Institute of Computer Science, 2004. 464 p. (in Russian)

12. Frisman E.Ya., Neverova G.P., Revutskaya O.L. Complex Dynamics of the Population with a Simple Age Structure. Ecological Modelling, 2011, vol. 222, issue 12, pp. 1943-1950. DOI: $10.1016 /$ j.ecolmodel.2011.03.043

13. Lobanova E.V., Medvedeva N.B. Smooth Models of Biological Populations. Bulletin of the South Ural State University. Series: Mathematical Modelling, Programming and Computer Software, 2014, vol. 7, no. 2, pp. 55-65. (in Russian) DOI: 10.14529/mmp140205

14. Kulakov M.P., Neverova G.P., Frisman E.Ya. Multistability in Dynamic Models of Migration Coupled Populations with an Age Structure. Russian Journal of Nonlinear Dynamics. 2014, vol. 10 , no. 4, pp. 407-425. (in Russian) DOI: $10.20537 / \mathrm{nd} 1404002$ 
15. Weidlich W. Sociodynamics: a Systematic Approach to Mathematical Modelling in the Social Sciences. Boca Raton, CRC Press, 2000. 392 p.

16. The Official Website of the Federal State Statistics Service (2016). Available at: http://www.gks.ru (accessed 5 May 2016).

17. The Demographic Yearbook of Russia. 2015. Statistical Yearbook, Rosstat. Moscow, 2015. $263 \mathrm{p}$.

Received October 18, 2016

УДК 51-7+314.15

DOI: $10.14529 / \mathrm{mmp} 170307$

\title{
ГРАВИТАЦИОННАЯ МОДЕЛЬ ДИНАМИКИ ЧИСЛЕННОСТИ НАСЕЛЕНИЯ
}

\section{М.Ю. Хавинсон, М.П. Кулаков}

Институт комплексного анализа региональных проблем ДВО РАН, г. Биробиджан

\begin{abstract}
В статье рассматривается авторская математическая модель динамики численности населения территорий с учетом миграции между ними. Модель является системой обыкновенных дифференциальных уравнений с постоянными коэффициентами. Основной идеей представленного в статье моделирования является учет миграционных взаимодействий территорий в виде нелинейных членов (попарных произведений фазовых переменных численности территорий). Такой подход позволяет, с одной стороны, рассматривать модель как вариант расширения гравитационного подхода в исследованиях миграции, с другой стороны, применять подходы математической биологии, успешно используемые в эконофизике и социодинамике. Для верификации модели использованы статистические данные о численности населения и миграции по федеральным округам РФ. Результаты моделирования показывают существенную значимость «отталкивания» мигрантов, прибывающих в центральные и северо-западные федеральные округа, преимущественно в близлежащие регионы (Южный, СевероКавказский и Приволжский федеральные округа). Получены модельные оценки миграционного сальдо, которые превышают статистические в десятки раз и, по всей видимости, описывают «скрытую» миграцию населения, охватывающую как долгосрочные, так и краткосрочные перемещения. Проведен анализ изменения стационарных значений численностей при линейном изменении параметров. Показано, что существуют такие значения параметров миграционной привлекательности федеральных округов РФ, при которых происходит увеличение численности населения как в целом по РФ, так и по отдельным округам. Установлено, что такие изменения могут происходить за счет существенных различий в возможностях, которые «предоставляют» для мигрантов разные федеральные округа (условия жизни и труда, воспитания и образования детей, и т.п.), и внутрироссийской миграции.
\end{abstract}

Ключевые слова: гравитационный подход; миграция; численность населения; федеральные округа РФ; обыкновенные дифференциальные уравнения.

\section{Литература}

1. Мищук, С.Н. Особенности международной трудовой миграции из Китая в Россию (на примере Дальневосточного федерального округа) / С.Н. Мищук // Экономика региона. - 2014. - № 2 (38). - С. 194-202.

2. Мищук, С.Н. Ретроспективный анализ миграционных процессов в Еврейской автономной области / С.Н. Мищук // Региональные проблемы. - 2015. - Т. 18, № 3. - С. 74-81. 
3. Motrich, E.L. Migration Processes in the Socioeconomic Development of the Far East E.L. Motrich, S.N. Naiden // Studies on Russian Economic Development. - 2015. - Issue 26. № 5. - P. 491-498.

4. Khavinson, M.Yu. Prediction of Foreign Labor Migration Dynamics at the Regional Level / M.Yu. Khavinson, M.P. Kulakov, S.N. Mishchuk // Studies on Russian Economic Development. - 2013. - V. 24, № 2. - P. 170-178.

5. Романовский, М.Ю. Введение в эконофизику: статистические и динамические модели / М.Ю. Романовский, Ю.М. Романовский. - М.; Ижевск: Ин-т компьютерных исследований, 2012. - 340 с.

6. Хавинсон, М.Ю. Эконофизика: от анализа финансов до судьбы человечества / М.Ю. Хавинсон // Пространственная экономика. - 2015. - № 1. - С. 144-166.

7. Василенко, П.В. Гравитационные силы и миграционная подвижность населения региона / П.В. Василенко // Вестник Балтийского федерального университета им. И. Канта. Серия: Естественные и медицинские науки. - 2013. - Вып. 7. - С. 155-159.

8. Драпкин, И.М. Гравитационный подход к эмпирической оценке факторов прямых зарубежных инвестиций в российской экономике / И.М. Драпкин, О.С. Мариев, К.В. Чукавина // Вестник Уральского федерального университета. Серия: Экономика и управление. - 2014. - № 6. - С. 58-66.

9. Каукин, А.С. Особенности эмпирических оценок гравитационной модели внешней торговли России / А.С. Каукин // Российский внешнеэкономический вестник. - 2013. № 4. - С. 71-84.

10. Чернавский, Д.С. Синергетика и информация: Динамическая теория информации / Д.С. Чернавский. - М: УРСС, 2016. - 304 с.

11. Ризниченко, Г.Ю. Биофизическая динамика продукционных процессов / Г.Ю. Ризниченко, А.Б. Рубин. - М.; Ижевск: Ин-т компьютерных исследований, 2004. - 464 с.

12. Frisman, E.Ya. Complex Dynamics of the Population with a Simple Age Structure E.Ya. Frisman, G.P. Neverova, O.L. Revutskaya // Ecological Modelling. - 2011. - V. 222. P. 1943-1950.

13. Лобанова, Е.В. Гладкие модели биологических популяций / Е.В. Лобанова, Н.Б. Медведева // Вестник ЮУрГУ. Серия: Математическое моделирование и программирование. 2014. - T. 7, № 2. - С. 55-65.

14. Кулаков, М.П. Мультистабильность в моделях динамики миграционно-связанных популяций с возрастной структурой / М.П. Кулаков, Г.П. Неверова, Е.Я. Фрисман // Нелинейная динамика. - 2014. - Т. 10, № 4. - С. 407-425.

15. Weidlich, W. Sociodynamics: a Systematic Approach to Mathematical Modelling in the Social Sciences / W. Weidlich. - Boca Raton: CRC Press, 2000. - 392 p.

16. Официальный сайт Федеральной службы государственной статистики. - URL: http://www.gks.ru (дата обращения: 05.05.2016).

17. Демографический ежегодник России. 2015: стат. сб. / Росстат. - М., 2015. - 263 с.

Михаил Юрьевич Хавинсон, кандидат экономических наук, старший научный сотрудник, Институт комплексного анализа региональных проблем ДВО РАН (г. Биробиджан, Российская Федерация), havinson@list.ru,

Матвей Павлович Кулаков, научный сотрудник, Институт комплексного анализа региональных проблем ДВО РАН (г. Биробиджан, Российская Федерация), k_matvey@mail.ru.

Поступила в редакиию 18 октября 2016 г. 